\author{
KÁllai ERNő Ph.D, HABIL
}

kallai@szte.jgypk.hu

főiskolai tanár (SZTE JGYPK), tudományos munkatárs (MTA TK KI)

\title{
Iskolaigazgatók véleménye Nógrád megyéből
}

\section{Opinions of school principals from Nógrád County}

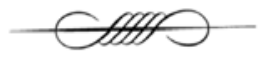

DOI 10.14232/belv.2018.3.8ｈttps://doi.org/10.14232/belv.2018.3.8

Cikkre való hivatkozás / How to cite this article: Kállai Ernő (2018): Iskolaigazgatók véleménye Nógrád megyéből. Belvedere Meridionale 30. évf. 3. sz. 141-150. pp.

ISSN 1419-0222 (print) ISSN 2064-5929 (online, pdf)

(Creative Commons) Nevezd meg! - Így add tovább! 4.0 (CC BY-SA 4.0)

(Creative Commons) Attribution-ShareAlike 4.0 International (CC BY-SA 4.0)

www.belvedere-meridionale.hu

A 2016-2018-ban az MTA Társadalomtudományi Kutatóközpont Kisebbségkutató Intézetének „Inkubátor” kutatási programjának keretében a Nógrád megyei romák társadalmi helyzetét térképeztük fel. Ennek során 10 településen 200 családi kérdőív felvételére került sor, valamint 70 interjú készült, továbbá megfigyelések, iskolai óralátogatások, fókuszcsoportos beszélgetések zajlottak. Az elkészült tanulmányokat tartalmazó kötet 2018-ban jelenik meg.

A kutatás fontos része volt a települések iskoláinak, azok vezetőinek, az ott dolgozó pedagógusok véleményének a megismerése. Mostani forrásközlésünkben négy iskolaigazgatóval készült interjúból választottunk ki részleteket. Elsősorban néhány olyan részt tesszük közzé elemzés és kommentár nélkül, amelyek a települések általános jellemzéséről, valamint az iskola helyzetéről szólnak. Különösen érdekesnek tünik a kistelepülések iskoláinak állapota, az épületek és a környezet helyzete. Hasonlóan fontos megítélés alá esik a tanári kar összetételével, a szakszerű oktatással kapcsolatos körülmények megismerése, illetve a szülőkkel történő kapcsolattartás problematikája. Végül pedig 
idézünk véleményt a mostanában sokszor vitatott „roma felzárkóztatással” kapcsolatos kérdésből, valamint a kistelepülési, etnikailag homogén iskolák lehetséges jövőjével kapcsolatos víziókból is.

A hosszabb beszélgetésekből kiragadott, most közölt interjúrészleteket Bogdán Mária, Fejős Anna, Keresztes-Takács Orsolya és Máté Dezső készítették, a kutatás vezetője Kállai Ernő volt.

\section{I.}

- Egy gyönyörű helyen fekvő kisváros, de nagy a szegénység. Azt látom, hogy nagyon kevés a munkahely ebben a városban és a környékén is. Az emberek mintha már ehhez szoktak volna hozzá. Nagyon sok a dolgozni eljáró ember. Ez a gyorsan épülő 21-es is segít ebben, meg hogy Budapesten könnyen találnak munkát és elmennek. Nagyon sokan járnak Budapestre, itt a környéken nem nagyon van állás, kevés a munkahely. Többen, ugyanúgy, ahogy az országban sokan, külföldre mentek el dolgozni. A munkatársaim közül is van, akinek a házastársa külföldön dolgozik. Ez egy hátrány. Ahol a szülők nincsenek odahaza, csak nagyon későn, és az egyik szülő hiányzik, mert hónapokig külföldön él, ott a gyereknek a nevelése sok nehézséget jelent a család részéről.

\section{- A tömegközlekedés?}

- Nagyon jó a vasúthálózat. A Salgótarján-Hatvan vonalon szinte óránként megy vonat. A távolsági buszok is nagyon jók.

\section{- Említette a szegénységet. Milyen mértékú a településen?}

- Én ezt a szülőkön közvetlenül érzékelem. Akkor, amikor különféle programok vannak, aminek költségvonzata is lenne, egy osztálykirándulás vagy bármilyen program, van egy rétege a szülőknek, akiknek ez már nehézséget jelent. Ilyenkor szoktuk a különféle alapítványainkat megkeresni. Ha roma tanulóról van szó, a roma kisebbségi önkormányzatot, hogy tudnának-e valamilyen segítséget nyújtani. A múlt évben is volt konkrét eset, egy roma tanuló nagyon tehetséges volt. Valamilyen versmondó, irodalmi területen. Egy olyan versenyre szerettük volna nevezni, ahol volt nevezési díj. Megkerestük a kisebbségi önkormányzatot, hogy segítsenek nekünk ebben, hiszen azt mondták, hogy partnerek. Valóban kapott is támogatást a gyerek a kisebbségi önkormányzattól.

\section{- Mi lett az eredmény?}

- Nagyon ügyes volt. Sikeres volt. Jól szerepelt. Egy kiugrási lehetőség volt számára.

\section{- Az iskolát hogyan jellemezné? Milyen állapotban van?}

- Amikor az állami átvétel volt, az önkormányzatok már nem költöttek az intézményeikre, amikor kiderült az, hogy át kell adniuk állami fenntartásba. Az állami intézményfenntartó először nem tudta, hogy mire számítson. Nem voltak pontos kimutatások, hogy mennyibe kerül a működtetése az intézménynek, és nem azzal kezdte, hogy fejleszti az intézményeket. Ez látszik az épületnek az állagán is. Nagyon sok probléma van, fejlesztésre szorulna az intézmény. A tankerület megpályázott egy nagyobb összegű fejlesztést, mintegy másfél milliárd forint összegben intézmény felújitás, bővítés, korszerüsítés. Ezt megnyerte, most nagyon sok iskolát fognak fejleszteni.

Az alsós épület egy műemlék jellegủ épület. Ahol minden átalakítás, fejlesztés, korszerűsítés engedélyekhez kötött, többletköltséget jelent. Elavult a csatorna rendszere. Ha valamit megbolygatunk, az már 10 millió forintokat jelent egy ilyen jellegü épületnél. Ez az épület pedig, 
ahol most vagyunk, egy „,szocreál” stílusú, ami már régóta felújításra szorul. Kevés a tantermünk. Nincsenek szaktantermeink, megfelelő számban szertáraink. Bővítésre is szükség van. Ugyanakkor, ha nemcsak az épületet nézem, esetleg az udvart is, hogy korszerübb sportpályák kellenének, korszerü berendezések, ahol egy kinti tanórát meg lehetne tartani. Egy 21. századnak megfelelő oktatást tartani.

Ez az iskola ugyanis nemcsak ennek a városnak az iskolája, hanem korábban volt egy kistérség, amelybe hét település tartozott. Ez a hét település most is ide járatja a gyermekeit. Ezek között van egy komplett nagyfalu, amelyik nem azért járatja ide, mert nem lett volna ki a tanulólétszáma az iskolának, hanem mert nem boldogultak a településen az oktatással.

\section{- Melyik ez a település?}

- Akkor én még nem voltam itt. Több mint 10 éve történt ez az integráció. Az elmondások alapján nem tudták sem fegyelmezni a tanulókat, sem pedig azt az oktatást biztosítani, amire szükség lett volna. A település P-vel együttmüködési megállapodást kötött. A gyerekeket behordják ide. Buszokkal jönnek, helyközi járatokkal. Alsótagozatnál, illetve már az óvodánál is adunk segítséget, kíséretet. A többi településről is buszok hordják általában a gyerekeket. Onnan kisbusszal jönnek. P. város segít, nagyon nagyvonalúan hozzájárulnak a bérlethez.

\section{- Milyen a pedagógusok felkészültsége ilyen sok gyerek különböző problémájára?}

- Nagyon magas szintű. Egyrészt idősebb pedagógusok vannak zömében. A nevelőtestületnek az átlag életkora 55 év feletti. Néhány új, fiatal kollégánk van, de ez elenyésző. Egy gyakornokunk. Évek óta nem volt gyakornok kollégánk. Most végre van három-négy kis fiatal kolléga.

Különböző egyetemeket, főiskolákat, tanfolyamokat elvégeztek. Ha arról beszélünk, hogy az esélyegyenlőség biztosítása nagyon fontos területe az intézményünknek, akkor gyakran kell fejlesztő órákat tartanunk. Nemcsak őket érinti, de nagyobb számban érinti a roma tanulókat, azt tapasztaljuk. Hét fejlesztő pedagógusunk van. Mindenkinek meg tudjuk adni azt, amire szüksége van. A szükséges órát, megfelelő csoportbontásban. Ebben a tanévben csak négy órát kellett kérnünk segítségként a pedagógiai szakszolgálattól, hogy teljesen meg tudjunk felelni a kihívásoknak.

(Nógrád megyei kisváros általános iskolájának igazgatója)

\section{II.}

\section{- Mit mesélne nekem a településről? Milyen állapotba van?}

- Hát... ez mindig polgármesterfüggő, úgy vettem észre. Most viszonylag agilis a polgármester, az előző nem nagyon volt az. Lehetett volna nekünk egy olyan iskolafölújítást csinálni, ahol napelemeket is kapunk. De nem vágott bele.

\section{- Látom, hogy most vannak napelemek máshol.}

- Ezt már az új polgármester csinálta, de ez nem az iskolánál van. De anno lehetett volna ezt az iskolát is úgy felújítani és legalább 5 évig kellett volna még utána üzemeltetni és ő ezt nem merte bevállalni. Akkor még önkormányzati fenntartásúak voltunk. Szóval, ezt én azért mindenféleképpen egy nagy negatívumnak tartom, hogy mi nem vagyunk fölújítva. 
Nehézségekbe ütközik egyébként a fölújítás, mert mindent a Müemlék Hivatallal kell intézni, mert ez egy műemlék épület. Gyönyörű kastély épület és akkor ez minden előnyével és hátrányával a miénk. Mert ugye a gyerekeknek ez azért rideg, strukturálatlan. Elhanyagoltnak tünik már belülről is. Sőt, piszkosnak is, mert minden pereg, mállik. Az udvarunkra, ha kimegy akkor ugyan nagy, de az is strukturálatlan, nincsen kialakított játszótér a gyerekeknek. Tehát, a focipályán kívül, meg a füves részeken kívül, jó, persze, tök jól elvannak itt a gyerekek, meg minden. Tehát, az nagyon-nagyon jó, városi szemmel nézve, de ezek a gyerekek meg szívesen vennének egy modern játszóteret. Mert, ha mi elvisszük őket egy városba, akkor le sem lehet őket szedni egy kuckóból, házikóból vagy valami csúszdáról.

\section{- Mióta van itt iskola ebben a kastélyban, kastélyépületben?}

- Azt hiszem, hogy 50 vagy 60 éve működik itt az iskola. Úgyhogy nem sok fölújítás volt azóta. Egyszer dőlt ki itt a timpanon, azt hiszem a hátsó részen, akkor muszáj volt megcsinálni a tetőnek a megerősítését.

$\mathrm{Na}$, és akkor hát a faluról annyit, amit én tudok még, hogy nagyon sok a bejáró dolgozó itt mindenfelé, de inkább szerintem Rétságon rengetegen dolgoznak közülük. Tehát, bármikor, még az én gyerekkoromba is, hogyha most így visszagondolok, akkor sok arcot látok itt a nyugdíjasok között, akit láttam Rétságon annak idején dolgozni. Akár hivatalba, akár itt, akár ott. Még a járási hivatal vezetőjét is innen származott. Úgyhogy valamikor ez virágzó település volt.

A cigányság az itt letelepedett, azt hiszem, hogy ők zenész cigányoknak tartották magukat. Ők már nem beszélik a nyelvüket igazából, a hagyományaikat se ápolják. Most indították be ezt, hogy mindenhol táncikálnak, meg népdalkórus, meg stb. és akkor ők is beindították, hogy táncolnak most. De igazából nem autentikus az ő táncuk, hogyha megnézi. Se a ruháik, se semmi. Tehát, ők már azok a fajta cigányok, akik olyan régen telepedtek le, hogy nem őrzik a hagyományaikat. Valamennyire megpróbáltak asszimilálódni, de azért az utolsó utcát, például néhány évvel ezelőtt jelölte ki az önkormányzat és ők maguktól odaköltöztek. Tehát, önmaguktól is azért valamennyire szegregálódnak. Persze laknak a faluba is bent.

\section{- Az mit jelent, hogy kijelölte az önkormányzat?}

- Hát hogy új utcát kell építeni, telkeket kell kijelölni, mert volt építkezési kedv éshát az új házakba, abba mind ők mentek. Nem tudom. Szóval, hogy nem megvettek házakat, hanem ott építettek újakat. Most már látom azt is, hogy ha kiöregedett valaki a házból, elhalt, akkor eladogatják. Nagyon alacsony áron tudják eladni és akkor beköltözgetnek.

$[\ldots]$

\section{- Hány tanár van az iskolában?}

- 11-en vagyunk. Összesen 14-en lehetnénk az igazgató és igazgató-helyettessel, de elvileg mind a 2 posztnak kéne lenni, de most velem együtt így 11-en vagyunk. Tehát itt igazából státuszhiány van már. Illetve státusz van, csak hiány van, nincsen feltöltve.

\section{- Elegendő szakos tanár van?}

- Hát, most nincsen jelen pillanatban, a szakos ellátottság nem sikerül 7-8-ban matekból. Mert 5-6-ban ugye műveltségterülettel egy tanító tanítja, tanítóból vagyunk sokan. Még ez a szerencse, 
mert a tanítókhoz nagyjából hozzászoknak a gyerekek, és ha följebb megyünk akármit tanítani, akkor azért nincs olyan nagy szörnyedelem, mint hogyha egy idegent hozunk be. Merthogy tavaly óraadó matektanárokkal oldottuk meg, idősekkel, szegények azt mondták, hogy idén már ők nem jönnek, nem figyelnek rájuk, nem vállalták. Matek szakos úgy volt még az utolsó tanítási nap is, hogy esetleg lesz, de aztán egy másik iskolát választott.

\section{- És akkor azt kik tanítják?}

- Én 7.-be elvállaltam. Ök a legrosszabb osztály. Gondoltam, hogy ne nyomjam senkire, akkor az már legyen az enyém. Szeretem amúgy a matekot, férjem is matek szakos meg az apukám is matek szakos, meg én is nagyon szeretem a matekot, úgyhogy ezzel így nincs baj ezen a szinten. Itt még tulajdonképpen mindent tudna tanítani egy tanító ezen a szinten. Mert itt nem a tehetséggondozásról van szó.

Jelen pillanatban nincsen történelem szakosunk, de a történelem szak azt úgy oldódott meg, hogy tavaly közhasznú munkásnak kaptam egy portást, aki régész-történész. És nyelvvizsgája van neki latinból, de nem kapta még meg a diplomáját, merthogy angolból is kéne neki egy nyelvvizsga. $\mathrm{Na}$, most ő nekünk tökéletesen bevált. A gyerekekhez ért, úgyhogy ő tanítja a történelmet most. Én azt gondolom, hogy így nem nagyon érdekel, hogy most szakos legyen, vagy ne, mert őt elfogadják a gyerekek, ő tud a nyelvükön. Így a történelem az biztosan megoldott.

Nekünk egyébként 3 közfoglalkoztatottunk van. Tehát, a portásunk az úgy van, hogy közfoglalkoztatott portás. Az iskola titkár is közfoglalkoztatott. Félévente hosszabbítják, illetve az egyik takarító, igen. És ez általános szerintem az iskolákban azért.

Az erkölcstant hitoktató tanítja. De hát ez mondjuk szerintem tökre belefér a dologba. És ő volt kint Németországba, mert ő a Z. vállalatnál dolgozott és ő jól beszél németül, úgyhogy ő tanítja a németet így. Mert német szakosunk sincsen. És akkor, ha így megnézzük, akkor utána nincsenek természettudományos szakjaink. Illetve, biológia-földrajzunk van. Tehát a természetismeret még elmegy, de a kémiát, azt nagyon régen a biológusunk tanítja, de azt már olyan nagyon régen mindig biológus tanította, hogy még régein is csak óraadóval volt megoldva egyszer, egyszer. Illetve a fizikát is, és az informatikát is. Tehát annyi szerencse, hogy például a Gyula, ő mondjuk az ELTE-n végzett rendszergazda is. Tehát, hogy azért egy ilyen rendszergazda, aki pedagógus végzettséggel van, az azért simán el tud tanítgatni informatikát ilyen szinten, heti 1 órába.

- És pont ők azok, akikre még az elején mondta, hogy nyugdíjba fognak menni nemsokára. - Hát igen. Ha úgy nézzük, hogy milyen az átlagéletkora a nevelőtestületnek, akkor itt az 50-hez közel nagyon-nagyon sokan vagyunk. Illetve 50-en fölül, meg még többen szerintem. És akkor vannak a fiatalok, mint például az a szegény, akinek most lett volna 19-én a minősítő vizsgája, mert gyakornok volt még, nagyon-nagyon jól ért ezekhez a gyerekekhez. Minket választott a Rétság helyett, mert ott is felajánlottak neki egy helyet, meg Tolmácson is, ahol lakik, és ide kijár, és itt dolgozik. És most például nincs meg neki az angol nyelvvizsgája, mert most se sikerült megcsinálni, és akkor most le kellett mondani a minősítő vizsgát. Tehát, tegnaptól fölmondtak neki.

\section{- Tényleg?}

- A törvény erejénél fogva megszünik a munkaviszony, hogyha nem csinálja meg a minősítést, azt meg le kellett mondani, mert nem tudta bemutatni a diplomáját. 


\section{- És akkor mi lesz az ő osztályával?}

- Maradni fog. Hát maradni fog, visszavesszük őt középfokú végzettséggel. Nincs kit beállítani. Mi nem tudunk felvállalni, tehát, mi eddig 26 órába tanítottunk, de úgy, hogy végig gyerekekkel voltunk. A 27-be meg mondjuk ebédeltettünk. Itt olyan nagy a hiány, hogy egészen egyszerüen jött tavaly jelentkező, de azt mondtam a kollegámnak, hogy nem is én akarom, vezesse végig ôt az osztályokon, nézze meg, hogy ezt ő tudja-e vállalni, mert én nem akartam zsákbamacskát árulni. Itt ez van. És akkor jött azzal, hogy hát ő nagyon jól tud tanítani matekot, de ő biztos, hogy nem fog tudni a gyerekekkel bánni. Hát akkor én meg azt mondtam, hogy akkor ezt át kell gondolni, mert itt a nagy része azon áll vagy bukik, hogy a gyerekekkel megtalálja a megfelelő hangot. Ha nem találja meg, akkor nem tud tanítani. Tehát, hogy azt mindenféleképpen ki kell alakítani, hogy őt elfogadják a gyerekek.

\section{(Nógrád megyei kisváros általános iskolájának igazgatója)}

\section{III.}

\section{- Hogyan jellemezné a települést?}

- Hát itt most lehet, hogy ketté kéne venni a társadalmat a romákra meg a nem romákra. Egyszerüen azért, mert a nem romák közössége az nagyon kiöregedő félbe van. És ez a kiöregedő fél is nagyon kevés életképes embert tartalmaz. Egyrészt azért, mert például a pedagógusok java része is bejáró. Tehát, nagyon kevés a helyben lakó. A fiatalok meg már évek óta nincsenek. Itt vannak az üres házak, az egyszemélyes házak, egy házaspár vagy csak a házaspárnak az egyik tagja lakik már csak itt. A településnek a nem roma része az ugye elöregszik. Beszéltünk arról, hogy a pedagógusok java része, talán hárman lakunk itt. Ugyanez vonatkozik az óvodára is, nagyon sok bejáró óvónő van, hiszen helyben egyszerűen nem tudjuk megoldani. A romaság, pedig amit mondtam, hogy pont azzal, hogy nevelőszülői státuszban vannak sokan, tehát ezzel így eléggé megerősödnek, gazdaságilag is, meg hát van feladatuk itt ebben a közösségben.

\section{- Hogyan látja, a roma lakosoknak milyen lehetőségeik vannak munkaügyben?}

- Vannak a közfoglalkoztatási programoknak a különböző változatai, ami évek óta müködik. Mindig vannak számukra továbbképzések. Elmúlt évben ilyen gyógynövénytermesztés volt, idén a kosárfonás. Tehát, valamilyen képzést mindig kapnak.

\section{- Tényleg kosárfonás volt ebben az évben?}

- Igen, igen, valahogy most tavasszal fejeződött be. Egyik kolleganőnk segített be nekik a képzésbe, tehát az elméleti dolgokat azt ő adta le, valami régi, 100 éves tanmenet, vagy tanterv alapján.

\section{- A gyógynövény-termesztés mit jelent számukra?}

- Megmondom őszintén, nem tudom. Tehát konkrétan azt, hogy mit tanultak és milyen céllal, hogy mi a szándéka az önkormányzatnak, tehát én úgy tudom, hogy az önkormányzat válogathatott, 
hogy milyen szakmában képzi ki itt a rá illetékeseket. Nem tudom, hogy miért esett a gyógynövényképzésre a választás. De hát voltak ennél már cifrább továbbképzések is. Pár évvel ezelőtt kötelező feladatként kaptuk a tankerülettől, hogy a romaságba különböző szakmák képzését kell megszervezni. Nekünk az útkarbantartó feladat jutott. Amit néztem, mert egyrészt óraszámba rengeteg gyakorlati rész volt, másrészt én, aki megbízást kaptam, nem értettem az útkarbantartáshoz, fizikai, műszaki képzettségem nem volt, nem is láttam át. Így ennek is az lett a vége, hogy a képzésre kötelezett volt az iskola is, meg az önkormányzat is és az önkormányzatnak a takarítónőjének jutott az a feladat, hogy az útkarbantartásnak az elméleti részét megfelelő óraszámban leadja a hallgatóknak. A gyakorlati képzés meg teljesen el is sikkadt. Tehát, papíron itt van tizenvalahány képzett útkarbantartó, aki szerintem akkor láttak utat, amikor fölültek az autóra vagy az autóbuszra. De hogy mit kezd esetleg egy kátyúval, vagy forgalomszervezési problémával, nem.

Igazából a probléma az, hogy mindenki tudja, hogy tanulni, képezni kell nemcsak a romákat, hanem mindenkit. Tehát ezt a szemléletet el tudja az ember fogadni, hogy igen is tanulni, tanulni kell. De az, hogy ebbe a közhasznú foglalkoztatásba bevont emberekre milyen képzést erőltetnek rá azon a jogcímen, hogy képezni márpedig kell, és tanulni kell, ennek nem látom az értelmét. Sőt, inkább a képzésnek meg a tanulásnak a lejáratása lesz az eredménye. Kérdéses ezeknek a képzéseknek a minősége. A másik probléma, hogy mit fog vele kezdeni.

Miként mondtam, idén tavasszal fejeződött be a kosárfonás, aminek én nagyon örülök, mert végül is nagyon klassz dolgokat lehet ezzel a kosárfonással csinálni. Tehát, biztos, hogy megtanulja ezeket a fogásokat, csak az életébe egy dolog hiányzik majd, a füzfavessző, amivel dolgozni lehetne.

(Nógrád megyei kisváros általános iskolájának az igazgatója)

\section{IV.}

\section{- A szülőkkel való kapcsolattartás mennyire múködik az iskola és a szülők között?}

- Általában egy évben három szülői értekezlet szokott lenni. Először évnyitó után, az első tanítási napon, az első osztályos szülőknek. A következő héten van egy összevont szülői értekezlet, tehát közösen nyitunk. Utána mindenki megy a saját osztályába. Kb. az első szülői értekezleten 50\%-os részvételi arány van. Az első osztályban magasabb a százalék, majdnem eléri a százat. Az idén egy szülő nem jött el az első osztályos gyerekének a szülői értekezletére.

A következő a félévi bizonyítvány osztás előtt, de inkább karácsony előtti részen. Ha a tanulmányi helyzettel vannak problémák, amellett, hogy kiértesítjük a szülőt, hogy ebből vagy abból a tantárgyból bukásra áll a gyerek, azért még szeretünk velük beszélni négyszemközt is, a szülői értekezlethez kapcsolódva. Én ezeket nem nagyon tartom hatásosnak. Én sokkal jobban szeretem a négy-, hat-, nyolcszem közti interakciókat, amikor egymás előtt kicsit rápirítok a rosszul állókra. Nem azért, hogy szégyelljék magukat, de legyen respektje annak a gyereknek, aki jól tanul. És a szülők is tartsák ezt észben. 
A másik dolog, hogy amikor probléma van, akkor négyszemközt beszéljük azt meg. A családlátogatás nem kötelező. Nem tudom kötelezni a fiatal kolléganőimet arra, hogy keresse fel a szülőket. Van rá lehetőség, hogy a családsegítővel együtt menjenek, meglátogassák a családokat. De az az igazság, hogy mi ismerjük a családokat, és én azt tartom, hogy ez az előre bejelentett időpont, hogy megyünk és kávézunk, kirakat, ennek semmi értelme. Nekem, ha valami problémám van, vagy valakit nagyon-nagyon meg akarok dicsérni, mert olyan jól tanul, akkor én váratlanul szoktam „betörni”. Akkor nincs felkészülés. Látom a maga valóságában, hogy mi történik. Bár előre tudom, meglepetés nem érhet. Akkor én ott elmondom. De erre nem tudom kötelezni a kollégáimat.

\section{- A családlátogatást mikor szokták alkalmazni?}

- Általában egy kis faluban alsótagozaton szokták alkalmazni, első osztályban, amikor megismerjük a gyereket. A későbbiek folyamán nem sok értelme van. De amíg én osztályfőnök voltam, én sürün látogattam a szülőket. Engem az utcán is megállítottak. Engem bármikor fel lehetett keresni. Az nagyon nagy dolog volt, hogyha én behívattam valakit. Én nem hívattam, hanem beültem az autóba és mentem. Én csináltam ilyeneket, amikor osztályfönök voltam, hogy gyertek, iszunk egy teát. Vagy a gyerekeknek farsangi bál volt, ti mit gondoltok, hogy lehetne olcsóbban kihozni a ruhákat vagy amit szeretnénk? Ti mit szóltok hozzá? Teljesen más volt a hangvétel. Ezek az alkalmak konstruktívabbak, hatásosabbak voltak. Itt nagyon oda kell figyelni arra, hogy milyen módszereket alkalmazunk a szülőkkel kapcsolatban. Könnyen át lehet a ló túlsó oldalára esni. A túlzott bizalmaskodás nem vezet eredményre. Én láttam, tapasztaltam, hogy a túl bizalmas viszony a visszájára fordul és onnantól kezdve veszekedés, utcán rákiabálás stb. van.

A hivatalos dolgokat tartsuk bent az iskolában, hivatalosan. Azt nem tudom mondani az osztályfőnöknek, hogy ki kell menned és ott intézd el. Ha másképp nem megy, hívd be a szülőt, leülünk és megbeszélünk mindent, hatszemközt. Nagyon nagy szükség van a megbeszélésre. Az üzengetés, a beírok az ellenőrzőbe, annak semmi értelme. Nekem jó kapcsolatom van a szülőkkel. Ha végigmegyek az úton, autóval is, van, amikor megállítanak, drága tanárbácsi. Imádom őket. Van egy-két ember, aki bekóstolt itt rögtön az elején. Biztosan tudsz róla, hogy vannak itt drogproblémák.

\section{- Nem. A többiek nagyon óvatosan beszéltek erről. Csak sejtem.}

- Vannak drogproblémák itt a településen. Volt már olyan, hogy bejött hozzám a szülő és egy pillanatra nem tudott megmaradni nyugton. Neki menni kell. Volt itt két rendőr, hogy miben tudnának segíteni. A két rendőr nem vette észre, hogy úgy be van lőve, mint az állat.

\section{- Mit használnak?}

- Herbal. Mindenféle ismeretlen porok. Mindenféle ismeretlen eredetü füféle. Nekünk erre is nagyon kell figyelnünk.

\section{- Jelen vannak-e a településen vagy az iskolában az etnikai konfliktusok?}

- Nem jellemző az iskolára az etnikai konfliktus, megmondom miért. Egy kicsit profánul hangzik: amikor 98 gyerekből 96 roma származású, konfliktus nem lehet. A maradék két gyereket meg tökéletesen elfogadják. Ha van is konfliktus, azért van, mert a Mónika, aki nyolcadikos, ő nagyon szeret tanulni, nagyon precíz, nem valami okos gyerek, de nagyon szorgalmas. Ö a szomszéd településen lakik, egyedüli bejáró itt az iskolában. Aranyos, kedves, jóindulatú, nem bántják a többiek. Legfeljebb azért csesztetik, mert neki megvan a házi feladata, a füzetvezetése tökéletes. 


\section{- Mert egy kis stréber?}

- Persze. De ez nem etnikai probléma. Itt a településen csak azokkal, abból kifolyólag vannak problémák, akik a békés egymás mellett élést megsértik.

\section{- De ez nem etnikai konfliktus?}

- Nem. Itt helyben tudják, hogy ki, melyik család, hova tartozik.

$[\ldots]$

- Hogyan járul hozzá szerinted az oktatási rendszer, illetve ez az iskola a roma gyerekek társadalmi integrációjához? Az elmúlt nyolc évben, ahogy divatosan mondják, a felzárkózásukhoz?

- Az, hogy az országos helyzet milyen, hogy a mai oktatási rendszer alkalmas-e arra, hogy a roma gyerekek hátrányait kompenzálja és olyan oktatást nyújtson, vagy lehetőséget arra, hogy a munkaerőpiacon tisztességesen helyt tudjanak állni, akkor erre határozottan azt mondom, hogy ez nem alkalmas arra. Ha azt kérdezed meg, hogy ez az integráció, ez alkalmas-e arra, hogy valamelyest segítsen ezeknek a gyerekeknek a sorsán, akkor megint csak az a válaszom, hogy nem. Ez az integráció nem integráció. El kell gondolkodni, hogy kit integrálunk kihez? Ott, ahol a roma népesség felül reprezentált, ott el kell gondolkodni, hogy kit kell integrálni? Hogyha egy 98 főből 96 roma származású és kettő nem roma származású, akkor milyen integrációról beszélek?

Amikor elkezdődött valamikor az integráció, itt arról szólt, hogy azokat a gyerekeket, akiket hátrányosan megkülönböztetve, szegregáltan oktattak, lásd enyhe fokban értelmi fogyatékos gyerekeket, és itt általában roma gyerekekről beszélünk, hogy ezt felszámoljuk. Ez nagyon jó kezdeményezés volt. Persze túlzásba estek ezzel is. Mert vannak olyan enyhe fokban vagy középsúlyos értelmi fogyatékosok, akik képtelenek a normál képességú gyerekekkel együtt haladni, ezt el kellett volna fogadni. Meg kellett volna ezeket az iskolákat részben hagyni, hogy ők a saját ütemükben tudjanak dolgozni és haladni. Olyan képzést kapni, amivel a munkaerőpiacra ők be tudnak törni és meg tudnak állni. De az a fajta integráció, ami elképzelt volt abban az időben, jó volt. Ott a normál képességű gyerekek közé betenni azokat a gyerekeket, akik csökkent értelmi képességủek vagy valamilyen részképesség zavarban szenvednek, együtt tanulni, plusz órát, plusz kedvezményt kapni, felzárkóztatni, fejleszteni, ez egy jó elképzelés volt.

Mára mást jelent az integráció. Most már nem arról van szó, hogy más képességbeli gyerekek, hanem a cigány és a nem cigánygyerekek integrációjáról van szó. És ez már nem ugyanaz, mint az eredeti elképzelés. Ez a ló túlsó oldala. Mert létrejöttek a szegregáció, illetve a deszegregáció kapcsán éppen ez ügyben a szegregált oktatási intézmények. Itt a szabad iskolaválasztást felül kellene bírálni szerintem. Itt az állami iskolákban egy egységes oktatási rendszert kellene biztosítani. Ahol mindenki a saját képességei szerint elsajátíthatja azokat a készségeket, ami az életkorának megfelelő és az ő személyiségének megfelelő. Aki azt mondja, hogy elviszem innen a gyerekemet, mert itt sok cigánygyerek van, nem biztos, hogy kimondja ezt, hanem azt mondja, hogy ő magasabbat, többet szeretne a gyerekének és ezért elviszi a katolikus iskolába, bárhová. Ebben az esetben én a törvényt megváltoztatnám. Azt mondanám, hogy aki az iskolából, a körzetéből elviszi a gyereket, az fizesse meg, áldozzon rá. 


\section{- Hogyan látja ennek az iskolának a jövőjét ezen a településen?}

- Hogyha ez a tendencia folytatódik, hogy a nem roma gyerekeket máshová íratják be és ide csak a roma gyerekek jönnek, plusz, ha a kormányunk betartja azt a törekvését, illetve azt a törvényt, hogy 14 fő alatt nem indítható önálló osztály, akkor ezzel a települési kisiskolákat tönkreteszik. Megszünteti a szegregációt, mert, hogy vége az iskolának. Be kell menni majd egy központi iskolába, amit létrehoznak, mert van erre pályázat, van erre törekvés. És jön az iskolabusz program, és mindenkit visznek be ebbe a nagy gyüjtőtáborba, az iskolába. Ott nem lesz az, hogy cigány vagy nem cigány. Ott mindenki együtt fog tanulni. Plusz azok az ún. elitiskolák vagy más képzést adó iskolák pedig még nagyobb tömegből tudnak meríteni saját tanulóbázist. Vagyis felvételi eljárással, képesség-, készségvizsgálattal. Általános iskolába sincs felvételiztetés. De megoldják most is.

Ez lesz a jövő. Az is tudvalevő, hogyha egy településen az iskola megszünik, akkor onnantól kezdve a településnek is vége, mert elvándorlás következik. A fiatalok mennek a munka után. Nemcsak a munka után, hanem a gyereknek a lehetőségei után is. Hogyha ez a tendencia így folytatódik, akkor az iskolát hiába újítjuk fel, hiába néz ki jól, hiába vannak digitális táblák. Majd lesz belőle civil ház, rendezvény ház. Az én településemen is civil ház müködik az iskola helyett. Mert ott már ez megtörtént. És nem cigánykérdés volt.

(Nógrád megyei kistelepülés általános iskolájának az igazgatója) 